\title{
The effects of kefir in mixed meals on appetite and food intake: a randomized cross-over trial
}

\section{Os efeitos do quefir em refeições mistas sobre o apetite e a ingestão de alimentos: um estudo randomizado cruzado}

\author{
Zeynep CAFEROGLU1 ID) 0000-0002-7226-5636 \\ Gizem AYTEKIN SAHIN1 1 (D) 0000-0002-6620-9259
}

A B S T R A C T

\section{Objective}

The natural probiotic kefir is fermented milk, and may have effects on satiety and voluntary energy intake. This randomized crossover trial aimed to determine whether kefir, consumed with low- or high-glycemic index meals, affects appetite and subsequent food intake.

\section{Methods}

Twenty four healthy females aged 21-24 years, were recruited from Erciyes University and the surrounding community. The participants were submitted to three different breakfasts: a low glycemic index accompanied by milk, a low glycemic index with kefir, and a high glycemic index with kefir, with a 1-week washout period between meals. At 0, 15, 30, 60, $90,120,150$, and 180 minutes after the meal, appetite ratings were measured by the visual analog scale, and then ad libitum lunch was served.

\section{Results}

No differences in appetite scores and voluntary energy intake were detected between the test meals. Furthermore, palatability ratings were similar between test meals, except for the higher score of high glycemic index kefir for overall palatability.

\section{Conclusion}

This study demonstrated that adding kefir to a high glycemic index meal may prevent increases in appetite and food intake, resulting in postprandial responses similar to those of a low glycemic index meal. These findings might enable the development of novel dietary strategies based on appetite regulation to treat or prevent obesity, particularly for Western societies. This trial was registered at ClinicalTrials.gov under the process NCT03636217.

Keywords: Appetite. Glycemic index. Kefir. Obesity. Probiotics.

\footnotetext{
${ }^{1}$ Erciyes University, Faculty of Health Sciences, Department of Nutrition and Dietetics. Kosk Street, n. 63, Melikgazi, Kayseri, Turkey.
} Correspondence to: Z. CAFEROGLU. E-mail: <zcaferoglu@erciyes.edu.tr>.

How to cite this article

Caferoglu Z, Aytekin Sahin G. The effects of kefir in mixed meals on appetite and food intake: a randomized cross-over trial. Rev Nutr. 2021;34:e190174. https://doi.org/10.1590/1678-9865202134e190174 


\section{RE S U M O}

\section{Objetivo}

O quefir probiótico natural é um leite fermentado, e pode ter alguns efeitos sobre a saciedade e a ingestão voluntária de energia. Este ensaio cruzado randomizado teve como objetivo determinar se o quefir consumido com uma refeição de baixo ou alto índice glicêmico teria afetado o apetite e a ingestão de alimentos subsequente.

\section{Métodos}

Vinte e quatro mulheres saudáveis, com idades entre 21 e 24 anos, foram recrutadas na Universidade de Erciyes e na comunidade circundante. Todas as participantes foram submetidas a três cafés da manhã diferentes: um baixo índice glicêmico e leite, um baixo índice glicêmico e quefir, e um alto índice glicêmico e quefir, com um período de lavagem de 1 semana entre as refeições. Aos 0, 15, 30, 60, 90, 120, 150 e 180 minutos após a refeição, as classificações de apetite foram medidas por escala analógica visual e, em seguida, o almoço ad libitum foi servido.

\section{Resultados}

Não foram detectadas diferenças nos escores do apetite e na ingestão voluntária de energia entre as refeições do teste. Além disso, as classificações de palatabilidade foram semelhantes entre as refeições de teste, exceto o maior escore de alto índice glicêmico quefir para palatabilidade geral.

\section{Conclusão}

Este estudo demonstrou que a adição de quefir a uma refeição com alto teor de índice glicêmico pode impedir o aumento do apetite e da ingestão de alimentos, resultando em respostas pós-prandiais semelhantes a uma refeição com baixo teor de índice glicêmico. Esses achados poderiam permitir o desenvolvimento de novas estratégias dietéticas baseadas na regulação do apetite para tratar ou prevenir a obesidade, particularmente para a sociedade ocidental. Esse julgamento foi registado na ClinicalTrials.gov como NCT03636217.

Palavras-chave: Apetite. Índice glicêmico. Quefir. Obesidade. Probióticos.

\section{INTROD U CTION}

Recently, Low-Glycemic Index (Gl) diets have been recommended as alternative dietary approaches for managing obesity, given that they may be more effective than traditional energy-restricted low-fat diets at reducing body weights by increasing satiety, decreasing food intake, and controlling glucose and insulin metabolism [1-4]. However, obesity has also been linked to low levels of physical activity and Western-style diets enriched in high-GI foods such as highly-refined carbohydrates [5]. Thus, the strict adherence to low-Gl diets may be difficult for obese people who have consumed Western-style diets for a long time. On the other hand, recent studies have suggested that gut microbiota modulating by pre and/or probiotics may be a new factor involved in weight management [6-8]. Dietary intervention studies have unveiled that probiotics may help to lose weight by providing appetite control, and reducing food intake $[9,10]$. However, the potential effects of probiotics combined with low- or high-GI meals/diets on satiety or voluntary food intake remain unknown. The aim of this study was to determine whether kefir, a natural probiotic, would have provided any beneficial effect on appetite and subsequent food intake, when consumed with low- or high-GI meals.

\section{METHODS}

Twenty four healthy females were recruited from Erciyes University and the surrounding community (Figure 1). Exclusion criteria were: following an energy-restricted diet; changes in body weight $>5 \mathrm{~kg}$ in the last three months; physician-diagnosed conditions; taking medications that influence the metabolism; having any chronic diseases; smoking; hypersensitivity for the food products under study; lack of appetite; being on a vegan diet; and being pregnant or lactating. 


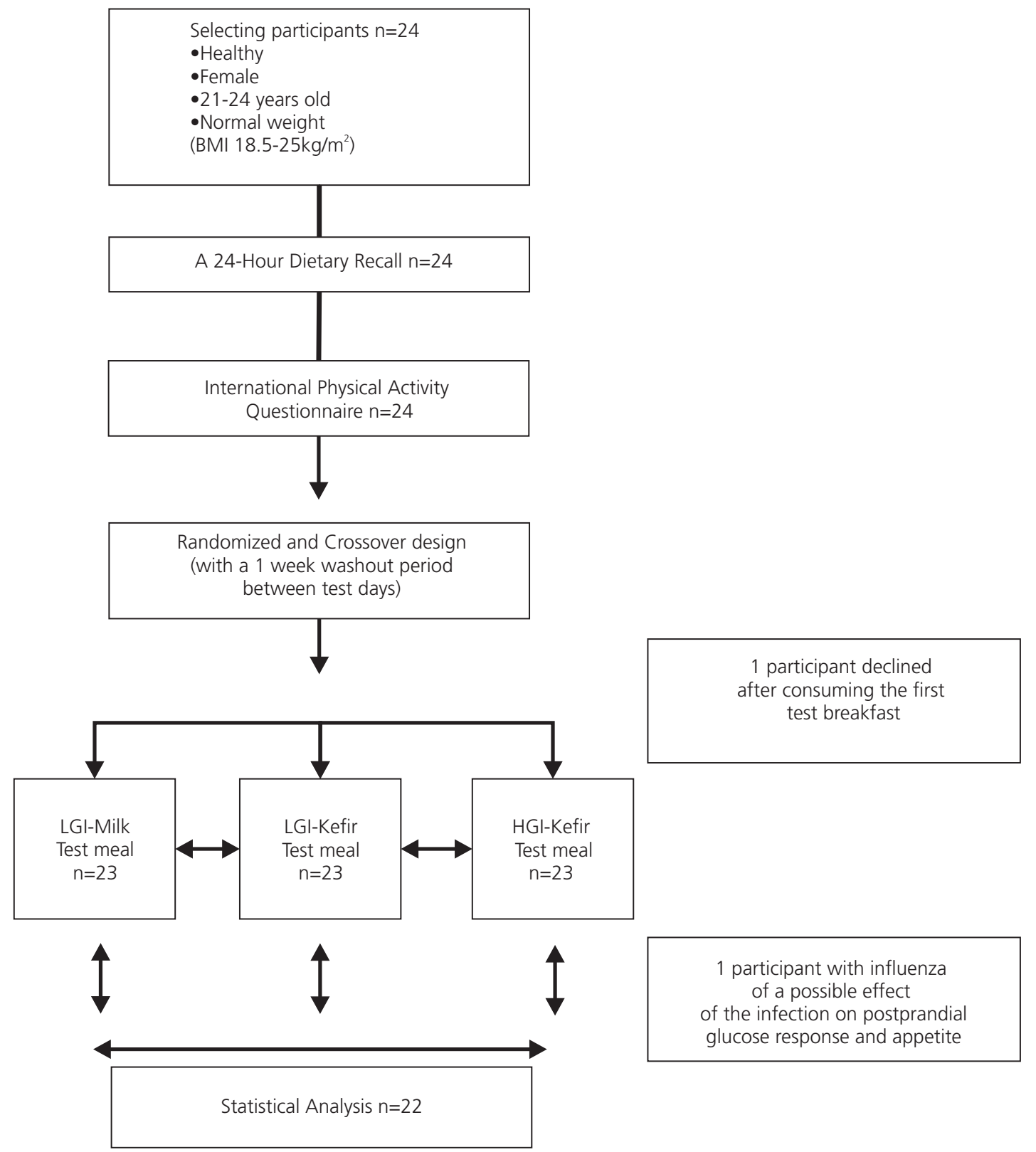

Figure 1. Participant recruitment flow diagram.

Note: BMI: Body Mass Index; LGI-Milk: Low Glycemic Index and Milk; LGI-Kefir: Low Glycemic Index and Kefir; HGI-Kefir: High Glycemic Index and Kefir.

The study was a randomized, single-blind, 3-intervention crossover trial. The participants were offered three different test meals with the following Gl amounts and milk or kefir: a low-Gl meal with milk content (LGI-Milk); a low-GI meal with kefir content (LGI-Kefir); and a high-GI meal with kefir content (HGIKefir). The primary outcomes were appetite sensations and subsequent food intake. Desire for specific types of food and palatability of the test meals were the secondary outcomes.

Participants received each test meal in a randomly assigned order on three different mornings separated by a washout period of 1-week, during which they were asked to maintain their usual diets and levels of physical activity. On the day before each test breakfast, participants were instructed to eat 
a standard meal at 9 p.m. and to avoid eating and/or drinking (except for water) and/or performing any physical activity beyond that of their typical daily activities. Furthermore, participants were tested in the follicular phase of their menstrual cycle to refrain from the possible effects of the menstrual cycle phases on appetite [11].

On each testing day, participants arrived in the testing room at 8:30 a.m. following a 12-hour fasting. Their anthropometric measurements (weight, height, waist, and hip circumferences) and dietary intakes with a 24-hour dietary recall were completed before eating the test meal. Also, first appetite scores were measured for baseline measurements (time zero). At 9 a.m. participants received the test meal without any information regarding its nutritional features and were instructed to consume it within 15 minutes. During the postprandial period, participants rested in the testing room and the appetite scale was applied at 15, 30, 60, 90, 120, 150 and 180 minutes. Moreover, participants were asked to assess the palatability of the test meal at 15 minutes (immediately after consuming test meal). No food or drink (except for water) was consumed following the test breakfast until an ad libitum lunch. In the first trial, water was available ad libitum, but the volume consumed was measured. In the second and third trials, participants drank the same volume as in the first trial. They were allowed to undertake sedentary activities, but not to sleep.

This study was conducted according to the guidelines laid down in the Declaration of Helsinki. All procedures were approved by the Clinical Research Ethics Committee of the Erciyes University (2016/547) on October $21^{\text {st }}, 2016$. All participants provided written informed consent for the study. The trial also registered at ClinicalTrials.gov under the process NCT03636217.

All breakfasts were matched for energy. The LGI-Milk and LGI-Kefir meals were also compared for macronutrients and GI, and the HGI-Kefir meal had a nearly two-fold difference in Gl (Table 1). Furthermore, both milk and kefir drinks contained $120 \mathrm{mg} / 100 \mathrm{ml}$ calcium, and the kefir drink also had $10^{7} \mathrm{CFU} / \mathrm{g}$ probiotic bacteria (Lactobacillus spp. and Streptococcus spp.). The GI of foods in test meals was estimated by using the Gl tables, with glucose as the reference food, and the average Gl for the meals was calculated [12].

Table 1. Nutritional composition of the foods in the test meals.

\begin{tabular}{|c|c|c|c|c|c|c|}
\hline Test Meals & Portion size ( $\mathrm{g} / \mathrm{mL})$ & Energy (kJ) & $\mathrm{AvCHO}^{*}(\mathrm{~g})$ & Protein (g) & Fat (g) & $\mathrm{GI}(\%)$ \\
\hline \multicolumn{7}{|l|}{ LGI-Milk } \\
\hline Milk (full-fat) & 200 & 524 & 9.9 & 5.8 & 6.8 & 31 \\
\hline Cheddar & 25 & 424 & 0.0 & 6.4 & 8.5 & 0 \\
\hline Apple & 200 & 469 & 24.9 & 0.9 & 0.9 & 36 \\
\hline Wholegrain bread & 50 & 435 & 19.1 & 4.8 & 0.9 & 50 \\
\hline Total & & 1,852 & 53.9 & 17.9 & 17.1 & 40 \\
\hline \multicolumn{7}{|l|}{ LGI-Kefir } \\
\hline Kefir (full-fat, plain) & 200 & 526 & 10.0 & 5.8 & 6.3 & 36 \\
\hline Cheddar & 25 & 424 & 0.0 & 6.4 & 8.5 & 0 \\
\hline Apple & 200 & 469 & 24.9 & 0.9 & 0.9 & 36 \\
\hline Wholegrain bread & 50 & 435 & 19.1 & 4.8 & 0.9 & 50 \\
\hline Total & & 1,854 & 54.0 & 17.9 & 16.6 & 41 \\
\hline \multicolumn{7}{|l|}{ HGI-Kefir } \\
\hline Kefir (full-fat, plain) & 200 & 526 & 10.0 & 5.8 & 6.3 & 36 \\
\hline Raspberry jam & 50 & 568 & 31.8 & 1.7 & 0.0 & 78 \\
\hline White bread & 75 & 773 & 34.0 & 7.0 & 1.5 & 70 \\
\hline Total & & 1,868 & 75.8 & 14.5 & 7.9 & 70 \\
\hline
\end{tabular}

Note: *Includes sugars and starch, excludes fiber.

AvCHO: Available Carbohydrates; GI: Glycemic Index; HGI-Kefir: High Glycemic Index and Kefir; LGI-Milk: Low Glycemic Index and Milk; LGI-Kefir: Low Glycemic Index and Kefir. 
At 180 minutes after the test meal, the ad libitum lunch was offered. Frequently consumed foods were used to prepare the lunch, which consisted of pasta with tomato sauce, a yogurt drink, and a mandarin. Participants were instructed to consume whatever they wanted and to eat until they felt comfortably full. Foods were weighted before consumption, and any remaining food was reweighed to determine the precise intake at lunch. Energy and macronutrient values were calculated using The National Food Composition Database (TurKomp), and manufacturer labelling.

A Visual Analog Scale (VAS) was used to estimate appetite ratings (hunger, fullness, desire to eat, and prospective food consumption), desire for specific food types (sweet, salty, savory, and fatty) and the palatability of test breakfasts (visual appeal, smell, taste, aftertaste, and overall palatability) [13]. Moreover, an additional measurement termed "composite appetite score" was produced by combining the separate VAS components such as hunger, fullness, desire to eat, and prospective food consumption. This validated appetite rating was calculated for each time point [14].

A power-based sample size calculation revealed that 21 participants were needed to provide $80 \%$ power to the test to detect a $5 \%$ difference between groups in the primary outcomes. To allow discontinuation during the study, 24 participants (considering losses of 15\%) were recruited, and the study was concluded with 22 participants.

Statistical analysis, based on previous research from Stevenson et al. [15], was applied by using the SPSS software (version 22.0, IBM SPSS Statistics). Data was expressed as the mean \pm SD unless otherwise indicated. The histogram, normal Q-Q plots, and also the Shapiro-Wilk test were used to assess normality. Furthermore, continuous variables were examined for skewness and kurtosis, and log-transformed before analysis and reported back-transformed geometric mean and standard error when required [16]. Postprandial appetite sensations were quantified as the Area Under the Curve (AUC) calculated according to the trapezoidal rule. One-way Analysis of Variance (ANOVA) for repeated measures was applied to determine statistical differences between groups. In addition, the data was analyzed by using 2-factor (time xmeal) repeated-measures ANOVA, and Bonferroni post hoc tests were executed to significant time $x$ meal interactions. For all statistics, $p<0.05$ was considered as statistically significant.

\section{RE S U LT S}

Participants' baseline characteristics were presented in Table 2. Participants' dietary intake and physical activity levels were similar before each test meal (data not shown). On all test days, participants fully consumed test breakfasts, and no digestive disturbances or complaints were recorded.

Table 2. Participants' baseline characteristics.

\begin{tabular}{lcc}
\hline & \multicolumn{2}{c}{ Values $(\mathrm{n}=22)$} \\
\hline Age, years & Mean & \pm SD \\
\cline { 2 - 3 } Anthropometric characteristics & 23.12 & \pm 0.81 \\
Height $(\mathrm{cm})$ & & \\
Weight $(\mathrm{kg})$ & 164.00 & \pm 4.23 \\
BMl $\left(\mathrm{kg} / \mathrm{m}^{2}\right)$ & 58.77 & \pm 6.09 \\
Waist circumference $(\mathrm{cm})$ & 21.82 & \pm 1.77 \\
Hip circumference $(\mathrm{cm})$ & 71.95 & \pm 5.89 \\
Waist/hip ratio & 95.95 & \pm 5.21 \\
\hline
\end{tabular}


Table 2. Participants' baseline characteristics.

2 of 2

\begin{tabular}{lrr}
\hline Characteristics & Mean & Values $(\mathrm{n}=22)$ \\
\hline Dietary intake* & & \pm SD \\
Energy (kcal/day) & $1,604.9$ & \pm 69.40 \\
Carbohydrate (E\%) & 44.95 & \pm 3.95 \\
Protein (E\%) & 15.44 & \pm 3.53 \\
Fat (E\%) & 39.38 & \pm 5.19 \\
Total MET (min/week) & $1,130.5$ & \pm 296.90 \\
\hline
\end{tabular}

Note: "Determined from the 24-hours dietary recalls using BeBiS Nutrition Database software version $7.2 ;{ }^{* *}$ The values correspond to the geometric means and standard error.

BMI: Body Mass Index; E: Energy; MET: Metabolic Equivalent Task.

Fasting appetite scores were similar before each test meals ( $p>0.05)$. No differences were found in the composite and individual appetite scores between the test meals ( $p>0.05$; Figure 2, Table 3), and no crossover effect of test meal over a 3-hour period ( $p>0.05$ ).

No evidence was found to support that consuming the HGl-Kefir breakfast increased the energy intake from the ad libitum lunch meal $(p=0.580)$. Energy intake was $1879.2 \pm 46.6 \mathrm{~kJ}$ after the LGI-Milk breakfast, $1811.7 \pm 63.9 \mathrm{~kJ}$ after the LGI-Kefir breakfast, and 1870.5 $\pm 37.0 \mathrm{~kJ}$ after the HGI-Kefir breakfast. The macronutrient composition of the foods chosen in the lunch also did not differ between test meals $(p>0.05)$.

Fasting scores for each parameter were similar on the three test days ( $p>0.05)$. There have been no significant differences, except for a tendency toward a lower desire to eat sweet foods after consuming test meals with kefir compared to the ones containing milk (Table 3). Additionally, a crossover effect of the test meals on the desire for sweet and salty foods over a 3-hour period was found ( $p<0.05)$. At 180 minutes, lower desires to eat sweet foods were recorded following the HGI-Kefir meal than following the LGI-Milk meal $(p=0.042)$, but not following the LGI-Kefir meal $(p=0.079)$. Moreover, the desire for salty foods 15 minutes after the consumption of HGI-Kefir was higher than LGI-Milk ( $p=0.039)$ and similar with LGI-Kefir $(p=0.324)$.

Apparently the ratings for visual appeal, taste, smell, and aftertaste were similar after the LGI-Milk, LGI-Kefir, and HGI-Kefir test meals on the three test days ( $p>0.05)$. However, the HGI-Kefir meal $(65.68 \pm 28.29)$ had higher scores for overall palatability compared to the LGI-Milk (48.95 \pm 29.00$)$ and LGI-Kefir (49.95 \pm 24.42$)$ meals $(p=0.004)$.

Table 3. Postprandial appetite sensations following the consumption of test meals.

\begin{tabular}{|c|c|c|c|c|c|c|c|}
\hline \multirow{2}{*}{$A \cup C(m m X m i n)^{*}$} & \multicolumn{2}{|c|}{ LGI-Milk } & \multicolumn{2}{|c|}{ LGI-Kefir } & \multicolumn{2}{|c|}{ HGI-Kefir } & \multirow{2}{*}{$p^{* *}$} \\
\hline & Geometric mean & $\pm \mathrm{SE}$ & Geometric mean & \pm SE & Geometric mean & $\pm \mathrm{SE}$ & \\
\hline Hunger & 6,339 & \pm 680 & 5,998 & \pm 599 & 5,841 & \pm 711 & 0.797 \\
\hline Fullness & 8,563 & \pm 711 & 9,056 & \pm 624 & 9,194 & \pm 630 & 0.640 \\
\hline Desire to eat & 6,196 & \pm 772 & 6,357 & \pm 640 & 5,323 & \pm 827 & 0.425 \\
\hline Prospective food consumption & 5,927 & \pm 677 & 5,920 & \pm 662 & 5,333 & \pm 743 & 0.682 \\
\hline Desire for sweet foods & 3,126 & \pm 960 & 1,982 & \pm 857 & 1,954 & \pm 552 & 0.385 \\
\hline Desire for salty foods & 4,833 & \pm 683 & 4,295 & \pm 780 & 5,211 & \pm 1011 & 0.497 \\
\hline Desire for savory foods & 2,329 & \pm 758 & 2,338 & \pm 847 & 3,838 & \pm 977 & 0.544 \\
\hline Desire for fatty foods & 1,427 & \pm 770 & 1,327 & \pm 720 & 1,416 & \pm 747 & 0.929 \\
\hline
\end{tabular}

Note: ${ }^{*}$ The values correspond to the geometric means and standard error, $\mathrm{n}=22 ;{ }^{* *}$ One-way ANOVA for repeated measures.

AUC: Area Under the Curve; LGI-Milk: Low Glycemic Index and Milk; LGI-Kefir: Low Glycemic Index and Kefir; HGI-Kefir: High Glycemic Index and Kefir. 

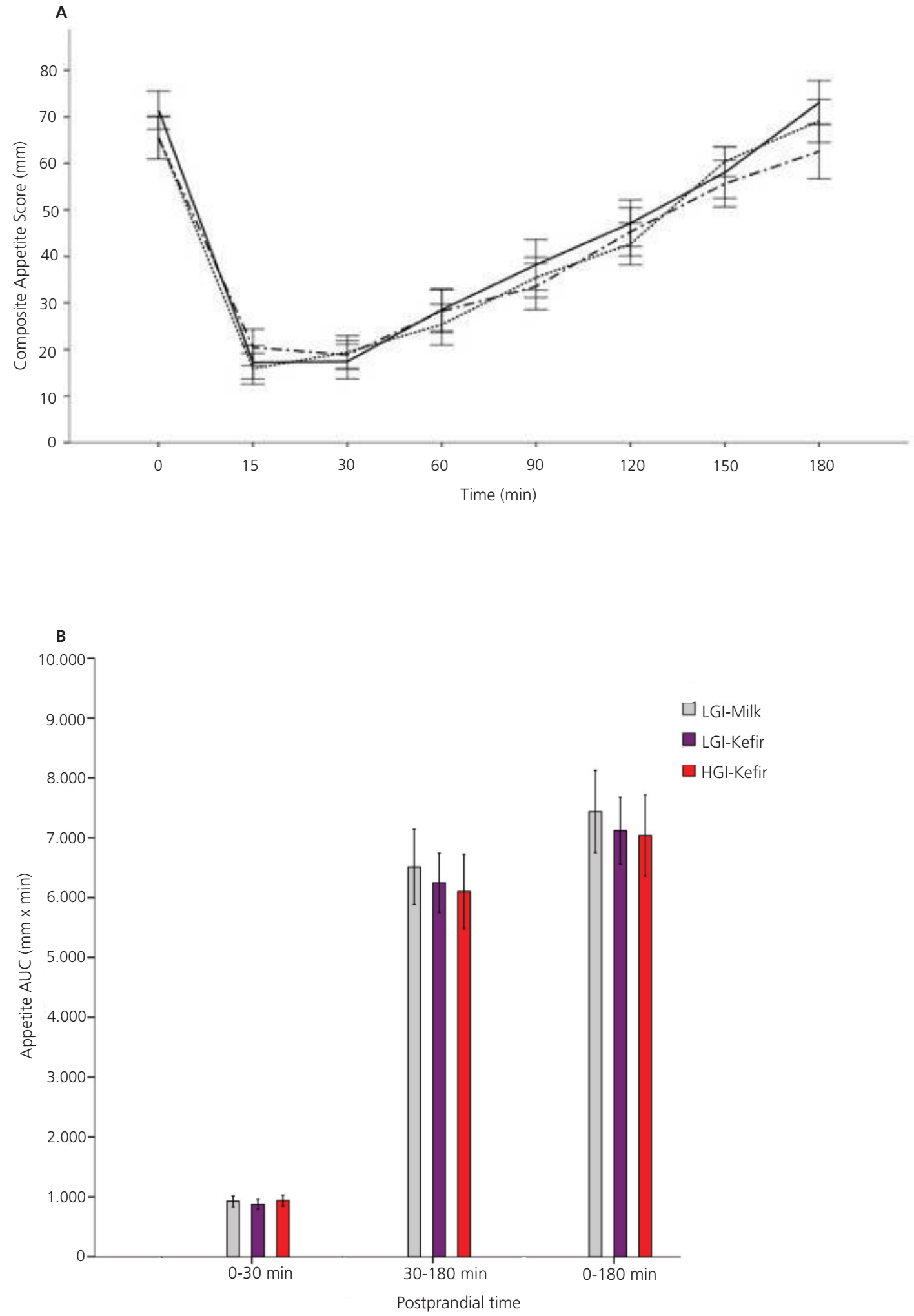

Figure 2. Mean composite appetite score (A), and the early, late, and total postprandial appetite responses (B) after each test meal over 3 hours ( $\mathrm{n}=22$ ). Note: *One-way ANOVA for repeated measures, p<0.05. Solid lines (-), LGI-Milk meal; Dashed lines (- -), LGI-Kefir meal; Dashed and dotted lines (- · -), HGI-Kefir meal. Bar charts show mean and S.E areas under the curve. HGI-Kefir: High Glycemic Index and Kefir; LGI-Kefir: Low Glycemic Index and Kefir; LGI-Milk: Low Glycemic Index and Milk. 


\section{DISCUSSION}

To our knowledge, the present study provides the first evidence of the effects of kefir, a natural probiotic, consumed with low- or high-GI meals, on appetite and voluntary food intake. The findings of the current randomized, crossover clinical trial have demonstrated that adding kefir to high-Gl meals may provide some beneficial effects on satiety and the subsequent food intake, even though consuming kefir with a low-Gl meal could have no extra beneficial effects. Moreover, there was no difficulty in consuming kefir instead of milk in terms of palatability.

With an increasing Gl related to Western-style diets rich in refined carbohydrates, it comes with no surprise that obesity, type 2 diabetes, and cardiovascular diseases are on the rise [5]. Mechanisms that explain the relationship between $\mathrm{Gl}$ and body composition are based on the effects of the GI on satiety [3, 17]. Previous studies have demonstrated that high-Gl foods/meals are associated with decreased satiety and increased food intake at a subsequent meal $[18,19]$. However, our results have shown that appetite sensations and subsequent food intake after the high-GI meal consumed with kefir were similar to those of found after the consumption of low-GI meals. The data obtained suggests that adding kefir to high-Gl meals/diets may help limit appetite and control energy intake.

The natural probiotic kefir, which has currently drawn the attention of health-care professionals, is fermented milk and consists of a complex microbial community including species of acetic and lactic acid bacteria and yeast. It is known that probiotic administration modulates gut microbiota composition and the state of hunger or satiety [7]. In our study, the effects of kefir and milk in the content of mixed meals on appetite sensations and subsequent food intake were examined, and there was no evidence of any difference between kefir and milk, when the Gl of breakfast was low and similar. This result may be due to the fact that both test meals have low GI and the same amount of calcium content. It is known that a low-Gl meal has salutary effects on postprandial glycemia and insulinemia, thus suppressing the appetite and reducing voluntary energy intake at a subsequent meal [20]. In addition, appetite has also been shown to associate with dietary calcium content [21]. Furthermore, there is evidence to suggest that the consumption of dairy products may regulate satiety and food intake through their constituents such as lactose, proteins, and a number of lipid components, containing medium-chain fatty acids and conjugated linoleic acid. Considering the effect of low Gls, calcium, and dairy foods on appetite and food intake, the present findings are expectable, and consistent with previous results [22].

Postprandial sensations of desiring different types of food were also investigated in this study. No significant differences were recorded in the desire for specific food types, except for a tendency toward lower desire to eat sweet foods after consuming test meals with kefir. In addition, while there was no difference between the test meals that included kefir, the desire to eat sweet foods was lower at 180 minutes and the desire for salty foods was higher 15 minutes after consuming HGI-kefir meal than LGIMilk meal. These findings suggest that kefir, especially when consumed with a high-Gl meal may have a beneficial effect to reduce the desire for sweet foods. However, this hypothesis could not be confirmed by the literature because no research was found regarding the effect of fermented milk products or probiotics on the desire for specific food types. Further clinical trials are needed to support our findings and elucidate the molecular and physiological mechanisms underlying the effect of probiotics on the desire for specific food types.

Palatability is undoubtedly an important factor to influence food selection and intake. The fermentation of milk using Lactic Acid Bacteria (LAB) is recognized to improve organoleptic attributes, and is not associated with any adverse effects on its palatability [23]. In agreement with the previous findings comparing whole milk and LAB-fermented milk, the visual appeal, taste, smell, and aftertaste ratings for 
test meals with milk or kefir were similar in our study [24]. However, the HGI-Kefir meal was found better in overall palatability than the LGI-Milk and LGI-Kefir meals. Due to the similar overall palatability rating in both low-GI meals with milk or kefir, a noticeable difference in HGI-Kefir was attributed to the high Gl instead of kefir. Unlike low Gl test meals, high GI meals contained sweetened foods, and sweetness is known as the most universally liked of all basic taste qualities [25]. Therefore, a meal/diet containing sugar or sweetened foods, such as Western-style diets, is generally among the most widely preferred choices.

The present study has some strengths. Firstly, appetite responses to kefir were evaluated in the content of breakfasts, which corresponds to a commonplace meal, instead of a probiotic supplement or single-food assessment. In addition, a strict control for potential confounders such as the menstrual cycle stage, physical activity level, and dietary intake on the previous day has been achieved in this study. Furthermore, the sensory experience of eating is an important driver of food selection and intake, and the current study measured palatability scores with appetite sensations on test meals. Nonetheless, there were several limitations that need to be addressed. One limitation is that it consisted of only of female participants, while appetite responses to test meals may differ by sex. Another limitation is that three test meals (LGI-Milk, LGI-Kefir, and HGI-Kefir) were examined in the current study, but the addition of a HGI-Milk meal could have strengthened our conclusions.

\section{CONCLUSION}

In conclusion, adding kefir to a high-Gl meal may prevent the increase in appetite and food intake, resulting in postprandial responses similar to those following a low-GI meal. However, when consumed in a low-GI meal, kefir had no advantages in comparison to milk. The palatability and acceptability of kefir by the participants also seemed similar to that of milk. These findings might enable the development of novel dietary strategies based on appetite regulation to prevent or treat obesity, particularly for the Western societies. However, it is unclear whether in the context of real-life mixed meals kefir would have affected postprandial glucose response and appetite-related hormones. Our results may lead to studies seeking evidence regarding the metabolic modulation of appetite by kefir or natural probiotics, when consumed with mixed meals.

\section{ACKNOWLEDGEMENTS}

We thank Damla Kocamaz, Eda Sahin, Gulsah Gunes, Hurmet Kucukkatirci, Merve Gursel, and Ozlem Cagir for their help with data collection. We are also grateful to all the participants of the study.

\section{CONTRIBUTORS}

Z CAFEROGLU conducted the planning of the study and statistical analysis; wrote the manuscript and had primary responsibility for the final content. G AYTEKIN SAHIN. contributed to the design and management of the research and in the preparation of the manuscript. All authors read and approved the final manuscript.

\section{REFERENCES}

1. Augustin LS, Kendall CW, Jenkins DJ, Willett WC, Astrup A, Barclay AW, et al. Glycemic index, glycemic load and glycemic response: an International Scientific Consensus Summit from the International Carbohydrate Quality Consortium (ICQC). Nutr Metab Cardiovas. 2015;25:795-815. https://doi.org/10.1016/j.numecd.2015.05.005 
2. Visuthranukul C, Sirimongkol P, Prachansuwan A, Pruksananonda C, Chomtho S. Low-glycemic index diet may improve insulin sensitivity in obese children. Pediatr Res. 2015;78:567-73. https://doi.org/10.1038/pr.2015.142

3. Juanola-Falgarona M, Salas-Salvado J, Ibarrola-Jurado N, Rabassa-Soler A, Diaz-Lopez A, Guasch-Ferre M, et al. Effect of the glycemic index of the diet on weight loss, modulation of satiety, inflammation, and other metabolic risk factors: a randomized controlled trial. Am J Clin Nutr. 2014;100:27-35. https://doi.org/10.3945/ajcn.113.081216

4. Wang ML, Gellar L, Nathanson BH, Pbert L, Ma Y, Ockene I, et al. Decrease in glycemic index associated with improved glycemic control among latinos with type 2 diabetes. J Acad Nutr Diet. 2015;115:898-906. https://doi. org/10.1016/j.jand.2014.10.012

5. Klees M, Dong Y, Cao M. Reversal effects of probiotic supplementation on a high glucose diet in caenorhabditis elegans model. Graduate Research and Discovery Symposium. 2015:194.

6. Firouzi S. Probiotics and glycemic control: a simplified interplay model for the pathways behind. Food Health. 2018;1:30-6.

7. Pimenta FS, Luaces-Regueira M, Ton AM, Campagnaro BP, Campos-Toimil M, Pereira TM, et al. Mechanisms of action of kefir in chronic cardiovascular and metabolic diseases. Cell Physiol Biochem. 2018;48:1901-14. https://doi. org/10.1159/000492511

8. Cerdó T, García-Santos JA, Bermúdez MG, Campoy C. The role of probiotics and prebiotics in the prevention and treatment of obesity. Nutrients. 2019;11:635-66. https://doi.org/10.3390/nu11030635

9. Mazloom K, Siddiqi I, Covasa M. Probiotics: how effective are they in the fight against obesity? Nutrients. 2019;11:258-82. https://doi.org/10.3390/nu11020258

10. Zoumpopoulou G, Pot B, Tsakalidou E, Papadimitriou K. Dairy probiotics: beyond the role of promoting gut and immune health. Int Dairy J. 2017;67:46-60. https://doi.org/10.1016/j.idairyj.2016.09.010

11. Chowdhury EA, Richardson JD, Tsintzas K, Thompson D, Betts JA. Carbohydrate-rich breakfast attenuates glycaemic, insulinaemic and ghrelin response to ad libitum lunch relative to morning fasting in lean adults. Br J Nutr. 2015;114:98-107. https://doi.org/10.1017/S0007114515001506

12. Vega-López S, Venn B, Slavin J. Relevance of the glycemic index and glycemic load for body weight, diabetes, and cardiovascular disease. Nutrients. 2018;10:1361-88. https://doi.org/10.3390/nu10101361

13. Gibbons C, Blundell JE. Quantifying appetite and satiety. In: Krentz AJ, Weyer C, Hompesch M. Translational research methods in diabetes, obesity, and nonalcoholic fatty liver disease. Springer: Cham; 2019.

14. Leidy HJ, Todd CB, Zino AZ, Immel JE, Mukherjea R, Shafer RS, et al. Consuming high-protein soy snacks affects appetite control, satiety, and diet quality in young people and influences select aspects of mood and cognition. J Nutr. 2015;145:1614-22. https://doi.org/10.3945/jn.115.212092

15. Stevenson EJ, Astbury NM, Simpson EJ, Taylor MA, Macdonald IA. Fat oxidation during exercise and satiety during recovery are increased following a low-glycemic index breakfast in sedentary women. J Nutr. 2009;139:890-7. https://doi.org/10.3945/jn.108.101956

16. Akin L, Kendirci M, Narin F, Kurtoglu S, Saraymen R, Kondolot M, et al. The endocrine disruptor bisphenol a may play a role in the aetiopathogenesis of polycystic ovary syndrome in adolescent girls. Acta Paediatr. 2015;104:e171-7. https://doi.org/10.1111/apa.12885

17. Shishehgar F, Mirmiran P, Rahmati M, Tohidi M, Tehrani FR. Does a restricted energy low glycemic index diet have a different effect on overweight women with or without polycystic ovary syndrome? Bmc Endocr Disord. 2019;19:93-104. https://doi.org/10.1186/s12902-019-0420-1

18. Zafar TA, Kabir Y, Ghazaii C. Low glycemic index foods suppress glycemic responses, appetite and food intake in young Kuwaiti females. Kuwait J Sci Eng. 2011;38:111-23.

19. Lennerz BS, Alsop DC, Holsen LM, Stern E, Rojas R, Ebbeling CB, et al. Effects of dietary glycemic index on brain regions related to reward and craving in men. Am J Clin Nutr. 2013;98:641-7. https://doi.org/10.3945/ajcn.113.064113

20. Sun FH, Li C, Zhang YJ, Wong SH, Wang L. Effect of glycemic index of breakfast on energy intake at subsequent meal among healthy people: a meta-analysis. Nutrients. 2016;8:37-51. https://doi.org/10.3390/nu8010037

21. Tremblay A, Doyon C, Sanchez M. Impact of yogurt on appetite control, energy balance, and body composition. Nutr Rev. 2015;73:23-7. https://doi.org/10.1093/nutrit/nuv015

22. Gonzalez JT, Green BP, Brown MA, Rumbold PL, Turner LA, Stevenson EJ. Calcium ingestion suppresses appetite and produces acute overcompensation of energy intake independent of protein in healthy adults. J Nutr. 2015;145:476-82. https://doi.org/10.3945/jn.114.205708 
23. Gemechu T. Review on lactic acid bacteria function in milk fermentation and preservation. Afr J Food Sci.e. 2015;9:170-5. https://doi.org/10.5897/AJFS2015.1276

24. Sanggaard KM, Holst JJ, Rehfeld JF, Sandstrom B, Raben A, Tholstrup T. Different effects of whole milk and a fermented milk with the same fat and lactose content on gastric emptying and postprandial lipaemia, but not on glycaemic response and appetite. Br J Nutr. 2004;92:447-59. https://doi.org/10.1079/bjn20041219

25. Reed DR, McDaniel AH. The human sweet tooth. Bmc Oral Health. 2006;6:S17-30. https://doi.org/10.1186/1472-68 31-6-S1-S17 